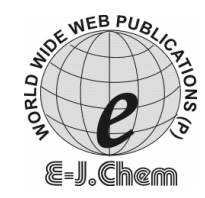

http://www.e-journals.net
ISSN: 0973-4945; CODEN ECJHAO

E-Journal of Chemistry

Vol. 5, No.4, pp. 713-717, October 2008

\title{
Spectrophotometric Determination of Adefovir Dipivoxil in bulk and Pharmaceutical Formulation
}

\author{
ZAHEER AHMED, Y.N.MANOHARA*, \\ K.P.CHANNABASAWARAJ and MANISH MAJUMDAR. \\ Department of Pharmaceutical Analysis, \\ National College of Pharmacy, Shimoga - 577201(K.S.) India. \\ Department of Pharmaceutical Analysis, \\ National College of Pharmacy, Shimoga - 577201(K.S.) India. \\ manohara_yn@yahoo.com
}

Received 8 January 2007; Accepted 5 March 2008

\begin{abstract}
Two selective and sensitive spectrophotometric methods have been developed for the estimation of adefovir dipivoxil in bulk and pharmaceutical preparations. Adefovir dipivoxil was subjected to acid hydrolysis and the hydrolysed product used for the estimation. The methods are based on the reaction with 3-methyl-2-benzothiazolinone hydrazone in the presence of ferric chloride, to form a colored species with absorption maxima at $627 \mathrm{~nm}$. The second method is based on the reaction of drug with 1,2 naphthaquinone -4-sulphonic acid sodium salt, under alkaline conditions which absorbs maximally at $454 \mathrm{~nm}$. Beers law is obeyed in the concentration range of $5-25 \mu \mathrm{g} / \mathrm{mL}$ and $2-10 \mu \mathrm{g} / \mathrm{mL}$ respectively. These methods were extended to pharmaceutical formulations and there was no interference from excepients and diluents. The analytical parameters were evaluated.
\end{abstract}

Keywords: Adefovir dipivoxil, MBTH, Folin's reagent.

\section{Introduction}

Adefovir dipivoxil is an antiviral drug and chemically [ 2-(6-aminopurine-9yl) ethoxy methyl(2,2-dimethyl propanoyloxy methoxy phosphoryl) oxy methyl 2,2-dimethyl propanoate ${ }^{1,2}$. Adefovir dipivoxil is a prodrug of adefovir. Adefovir is an acyclic nucleotide analong of adenosine monophosophate ${ }^{3}$. It is a new generation antiviral drug which is active in-vitro against HBV. It is indicated for the treatment of chronic hepatitis-B and HIV. It is not official in any pharmacopoeia. Literature survey reveals that no visible methods are reported however a few bio-analytical methods were reported using human plasma by $\mathrm{HPLC}^{4} \& \mathrm{LCMS} \mathrm{MS}^{5}$. 


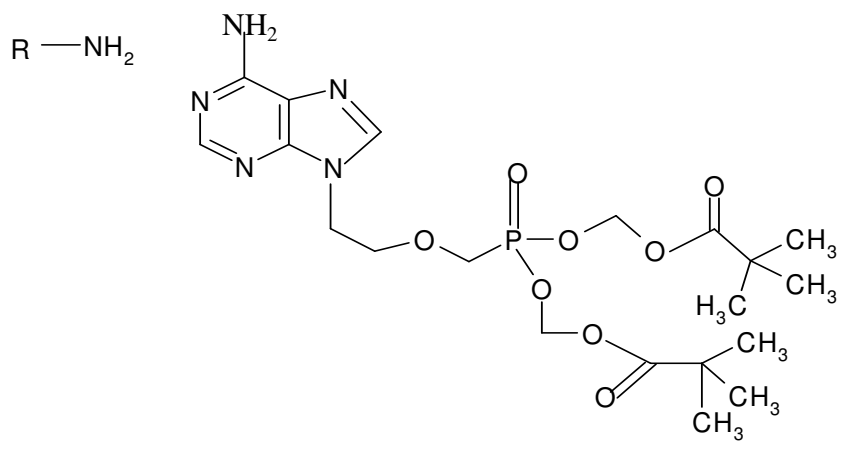

Figure 1. Structure of adefovir dipivoxil.

The present investigation has been undertaken to develop two simple visible spectrophotometric methods in which, the colored species obtained in method A, can be considered to be the oxidative coupling product between the acid hydrolyzed drug and MBTH in the presence of ferric chloride as an oxidant ${ }^{6}$, with a $\lambda_{\max }$ at $627 \mathrm{~nm}$. Methods B is based on the formation of colored chromogen at $\lambda_{\max } 454 \mathrm{~nm}$ when it reacts with $1,2-$ naphthaquinone - 4- sulphonate under alkaline conditions ${ }^{7}$.

\section{Experimental}

Shimadzu model 1700 double beam UV-visible spectrophotometer with a pair of $1 \mathrm{~cm}$ matched quartz cells was used to measure absorbance of the resulting solutions. All the chemicals used were of AR grade procured from qualigens Mumbai.

\section{Preparation of reagents}

3- Methyl-2- benzo thiazolinone hydrazones (0.2\%)

$200 \mathrm{mg}$ of MBTH was dissolved in $100 \mathrm{~mL}$ of distilled water.

\section{Ferric chloride (0.2\%)}

Ferric chloride $0.2 \%$ was freshly prepared by dissolving $200 \mathrm{mg}$ of ferric chloride in $100 \mathrm{~mL}$ of distilled water.

\section{Folins reagent (sodium 1,2-naphthaquinone -4- sulphonate) (1\%w/v)}

Folins reagent was prepared by dissolving $1 \mathrm{~g}$ of sodium 1, 2-naphthaquinone-4- sulphonate in $100 \mathrm{~mL}$ of distilled water.

\section{Sodium hydroxide $(5 \% \mathrm{w} / \mathrm{v})$}

Sodium hydroxide solution was prepared by dissolving $5 \mathrm{~g}$ in $100 \mathrm{~mL}$ of distilled water.

\section{Method A}

\section{Preparation of sample solutions}

Twenty tablets were powdered and an amount equivalent to $100 \mathrm{mg}$ of drug was dissolved in $50 \mathrm{~mL}$ of distilled water, $9.0 \mathrm{~mL}$ of concentrated $\mathrm{HCl}$ was added, refluxed for $2 \mathrm{~h}$ and the solution was diluted to $100 \mathrm{~mL}$ with distilled water to obtain $1 \mathrm{mg} / \mathrm{mL}$ solution. The hydrolyzed drug solution was filtered and further diluted with distilled water to obtain a concentration of $100 \mu \mathrm{g} / \mathrm{mL}$. 


\section{Preparation of standard solutions}

Accurately $100 \mathrm{mg}$ of drug was dissolved in $50 \mathrm{~mL}$ of distilled water, $9.0 \mathrm{~mL}$ of concentrated $\mathrm{HCl}$ was added, refluxed for $2 \mathrm{~h}$ and the solution was diluted to $100 \mathrm{~mL}$ with distilled water to obtain $1 \mathrm{mg} / \mathrm{mL}$ solution. The hydrolyzed drug solution was filtered and further diluted with distilled water to obtain a concentration of $100 \mu \mathrm{g} / \mathrm{mL}$.

\section{Assay procedure}

Aliquots of standard drug solution ranging form $0.5-2.5 \mathrm{~mL}(100 \mu \mathrm{g} / \mathrm{mL})$ were transferred to a series of $10 \mathrm{~mL}$ volumetric flasks. To each, $0.2 \mathrm{~mL}$ of $0.2 \% \mathrm{MBTH}, 0.2 \mathrm{~mL}$ of $0.2 \%$ of ferric chloride were added and stand for 20 minutes and the volume was made up to the mark with distilled water. The absorbance at $627 \mathrm{~nm}$ against a reagent blank was measured. The colored species was stable for $2.0 \mathrm{~h}$ and the amount of the unknown sample was computed from its calibration graph.

\section{Method B}

\section{Preparation of standard solution}

Standard solution of adefovir dipivoxil was prepared by dissolving $100 \mathrm{mg}$ in $100 \mathrm{~mL}$ of methanol and further diluted with methanol to get $100 \mu \mathrm{g} / \mathrm{mL}$.

\section{Preparation of sample solution}

Twenty tablets were weighed and powdered. The tablet powder equivalent to $100 \mathrm{mg}$ of adefovir dipivoxil was transferred into $100 \mathrm{~mL}$ volumetric flask containing $50 \mathrm{~mL}$ of methanol and the flask was kept for ultrasonication for $5 \mathrm{~min}$. It was then diluted up to the mark with methanol and the solution was filtered. Further it was diluted with methanol to obtain a concentration of $100 \mu \mathrm{g} / \mathrm{mL}$ and used for analysis.

\section{Assay procedure}

Aliquots of adefovir dipivoxil ranging from $0.2-1.2 \mathrm{~mL}$ of standard solution were transferred into a series of $10 \mathrm{~mL}$ volumetric flaks. To each flask $0.2 \mathrm{~mL}$ of sodium 1,2-naphthaquinone-4-sulphonate $(1 \% \mathrm{w} / \mathrm{v})$ and $2 \mathrm{~mL}$ of sodium hydroxide $(5 \% \mathrm{w} / \mathrm{v})$ solutions were added to each flask. It was kept for $20 \mathrm{~min}$ at room temperature. The solutions were made up to the mark with distilled water. The absorbance was measured at $454 \mathrm{~nm}$ against a reagent blank. The colored species was stable for several hours and the amount of the unknown sample was computed from its calibration graph.

\section{Results and Discussion}

The optical characteristics such as Beer's law limits, sandell's sensitivity, molar absorptivity, and percent relative standard deviation, (calculated from the eight measurement containing $3 / 4$ th of the amount of the upper Beers law limits) were calculated and the result are summarized in Table 1. 
Table 1. Optical characteristics and precision of the proposed method A and B

\begin{tabular}{|c|c|c|}
\hline Parameter & Method A & Method B \\
\hline$\Lambda \max , \mathrm{nm}$ & 627 & 454 \\
\hline Beers law limits, $\mu \mathrm{g} \mathrm{mL}^{-1}$, (c) & $5-25$ & $2-10$ \\
\hline Sandell's sensitivity $\mu \mathrm{g} / \mathrm{cm}^{2} / 0.01 \mathrm{~A} . \mathrm{U}$ & 0.045 & 0.010 \\
\hline Molar absorptivity, $\mathrm{L} \mathrm{mol}^{-1} \mathrm{~cm}^{-1}$ & $0.217 \times 10^{4}$ & $0.965 \times 10^{4}$ \\
\hline \multicolumn{3}{|l|}{ Regression equation, $\mathrm{Y}^{*}$} \\
\hline Intercept (a) & 0.0219 & 0.0944 \\
\hline Slope (b) & 0.0003 & 0.0046 \\
\hline Correlation Coefficient (r) & 0.9999 & 0.9996 \\
\hline Relative standard deviation, $\%$ & 0.3082 & 0.1839 \\
\hline \multicolumn{3}{|l|}{$\%$ Range of error** } \\
\hline Confidence limit, 0.05 level & 0.0011 & 0.0008 \\
\hline 0.01 level & 0.0016 & 0.0012 \\
\hline
\end{tabular}

Table 2. Assay and recovery of adefovir dipivoxil in pharmaceutical formulations.

\begin{tabular}{ccccccc}
\hline S.No & $\begin{array}{c}\text { Amount of } \\
\text { drug in } \\
\text { tablet, mg }\end{array}$ & $\begin{array}{c}\text { Amount of } \\
\text { pure drug } \\
\text { added, mg }\end{array}$ & $\begin{array}{c}\text { Content of } \\
\text { drug } \\
\text { found, mg }\end{array}$ & $\begin{array}{c}\text { Pure drug } \\
\text { percentage of } \\
\text { recovery ** }\end{array}$ & $\begin{array}{c}\text { Content of } \\
\text { drug found, } \\
\text { mg }\end{array}$ & $\begin{array}{c}\text { Pure drug } \\
\text { percentage of } \\
\text { recovery** }\end{array}$ \\
\hline Tablet-I & 10.0 & 5 & 14.98 & 99.73 & 14.92 & 99.46 \\
Tablet-II & 10.0 & 5 & 14.96 & 99.66 & 14.90 & 99.33 \\
\hline
\end{tabular}

** Recovery amount was the average or six determinations **

\section{Conclusions}

Commercial formulation of adefovir dipivoxil tablet was successfully analyzed by the proposed method. The accuracy and validity of the proposed methods were further ascertained by performing recovery studies. Pre-analyzed sample was spiked with pure drug and the total quantity was found by the proposed methods. The recovery of the pure drug added was quantitative and revealed that there is no interference of excipients in the determination. The results of recovery study were shown in Table 2. In conclusion the proposed spectrophotometric method for the estimation of adefovir dipivoxil is simple, sensitive, and accurate and can be used for the routine quality control of the drug in bulk as well as in pharmaceutical formulations.

\section{Acknowledgements}

The authors are grateful to the Head, Department of Pharmaceutical Analysis for providing research facilities, authors are also thankful to the National Education Society, Shimoga.

\section{References}

1. O' Neil MJ. The Merck Index - An encyclopedia of chemicals, drugs and biologicals, $13^{\text {th }}$ ed. New Jersy: Merk \& Co., INC, 2001. 
2. Sweetmann S C Martindale - The Complete Drug Reference, $33^{\text {rd }}$ Ed. Pharmaceutical press, London (UK), 2002.

3. Hadziyannis S J, Tassopoulos N C, Heathcote E J, Chang T T, Kitis G and Rizzetto M, N. Engl J Med., 2003, 348(9), 848-50.

4. Sparidans R W, Veldkamp A. Hoetelmans R M and Beijenen J H, J Chromatogr B.1999, 736.

5. Vela J E, Olson L Y and Huang A, J Chromatogr B Analyt Technol Biomed Life Sci. 2007, 848(2),335-43.

6. Gowri Shankar D, Sujatha N, Anil Kumar B and Latha P V M, Asian J Chem, 2007, 19(2), 1602-1604.

7. Nizamuddin S, Gurupadayya B M, Ravi.M C, Manohara Y N and Appala Raju S, Indian J Pharm Sci., 2007, 69(3), 451-453. 


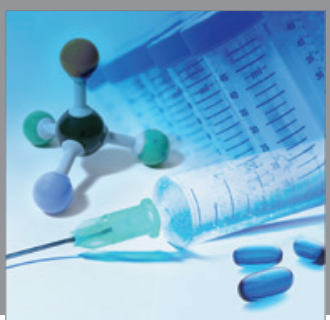

International Journal of

Medicinal Chemistry

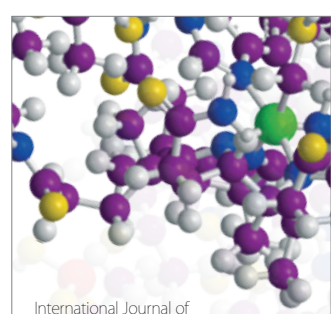

Carbohydrate Chemistry



The Scientific World Journal
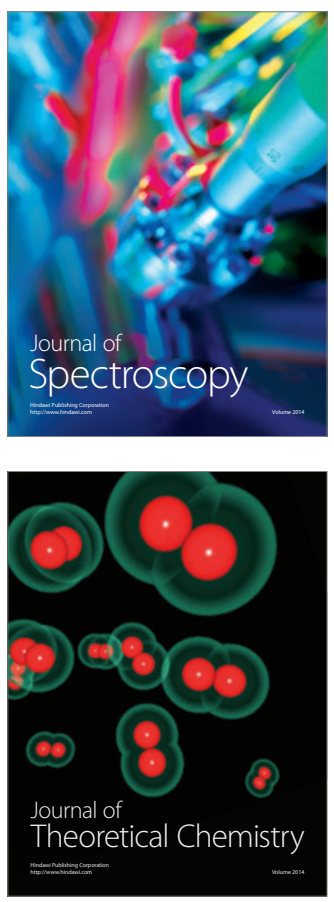
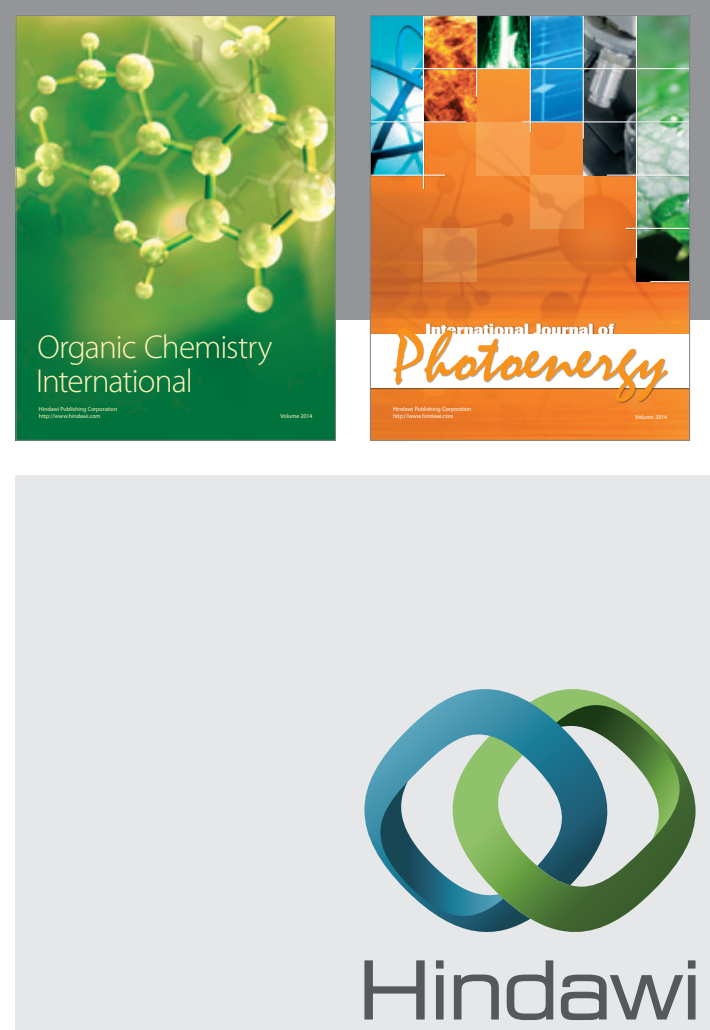

Submit your manuscripts at

http://www.hindawi.com
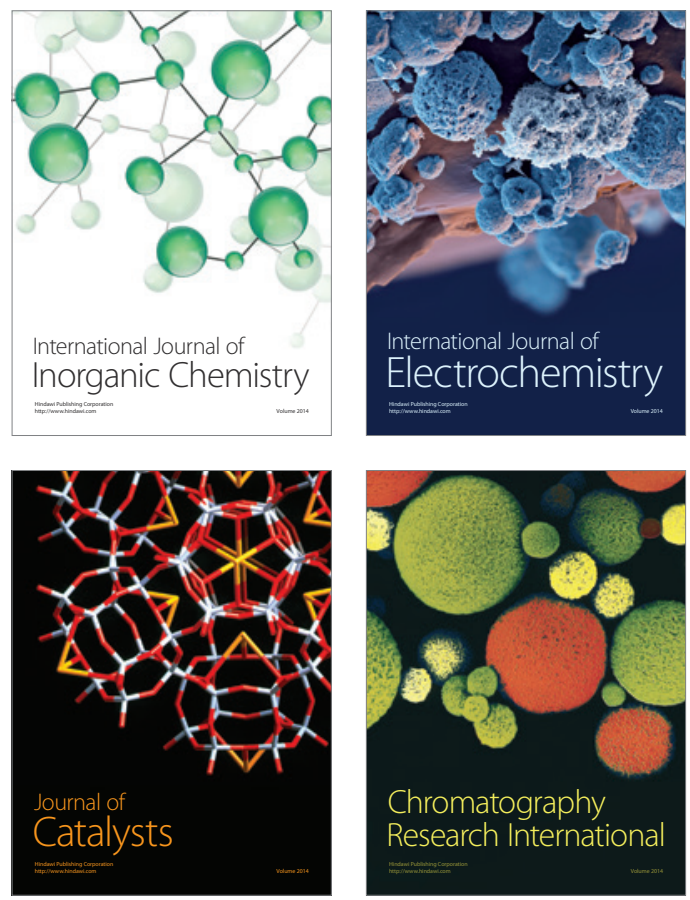
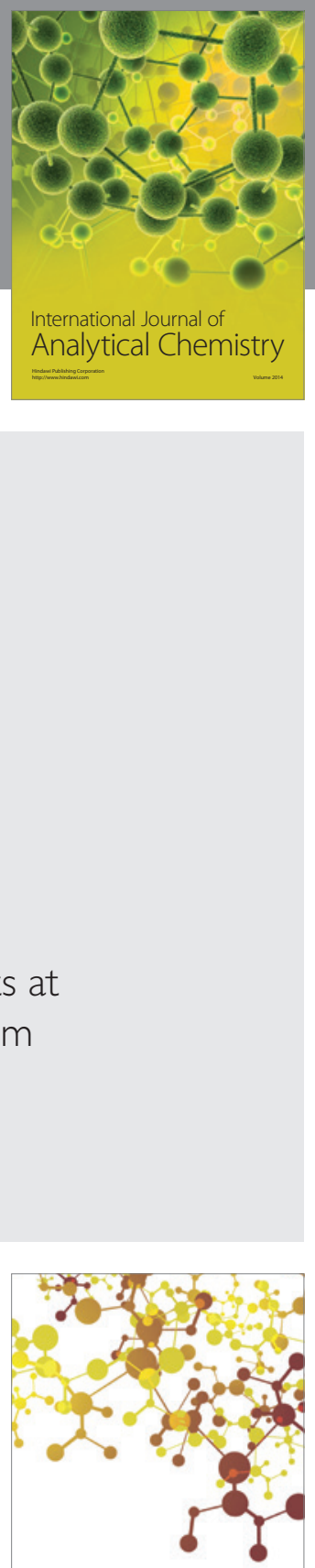

Journal of

Applied Chemistry
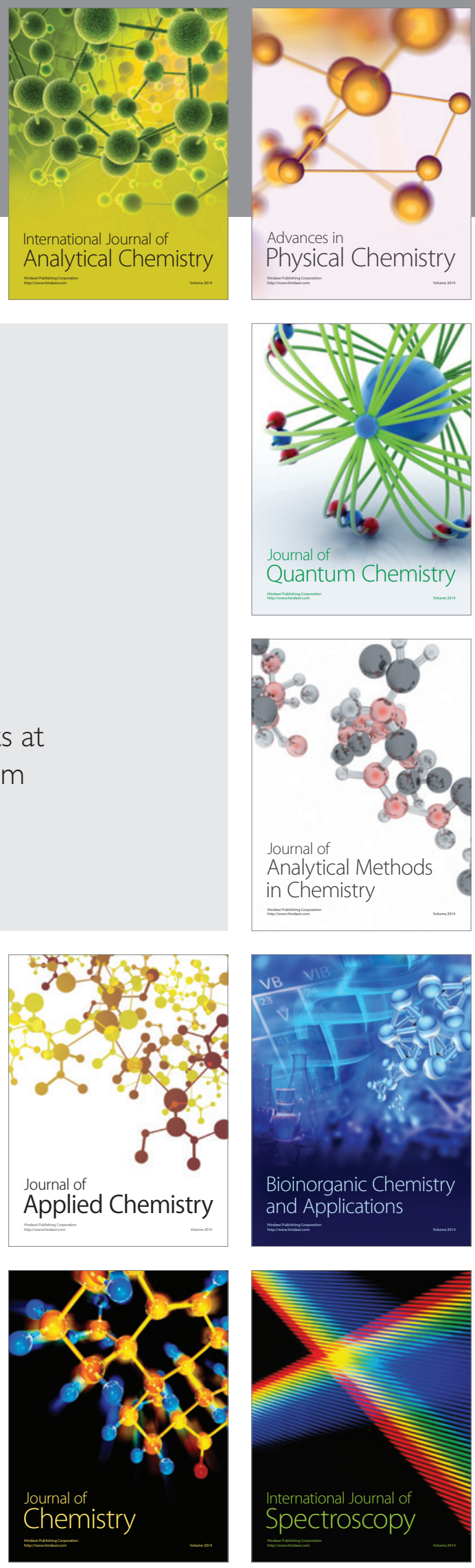